\title{
MENINGKATKAN PEMAHAMAN MATEMATIS SISWA DENGAN MENGAPLIKASIKAN MODEL PEMBELAJARAN TEAMS GAME TOURNAMENT (TGT) BERBASIS BAHAN AJAR GAMIFIKASI
}

\author{
Chinthia Adinti $^{1}$, Dwijowati Asih Saputri ${ }^{2}$, Rizki Wahyu Yunian Putra ${ }^{3}$ \\ Universitas Islam Negeri Raden Intan, Lampung ${ }^{123}$ \\ e-mail: chinthiadnt@gmail.com
}

\begin{abstract}
ABSTRAK
Penelitian ini bertujuan untuk meningkatkan pemahaman matematis siswa dengan mengaplikasikan model pembelajaran Team Game Tournament (TGT) berbasis bahan ajar gamifikasi. Peneliti menggunakan metode penelitian eksperimen dengan mengadopsi Quasy Experiment Design. Peneliti juga menggunakan cluster random sampling sehingga didapat kelas VIII A sebagai kelas eksperiment yang menggunakan model pembelajaran Teams Games Tournament (TGT), kelas VIII B kelas eksperiment yang menerapkan bahan ajar gamifikasi menggunakan model Teams Games Tournament (TGT), sedangkan kelas VIII C sebagai kelas kontrol yang pembelajarannya menggunkan metode tradisional. Hasil penelitian meunjukan bahwasanya terdapat pengaruh penerapan model pembelajaran teams games tournament (TGT) menggunakan bahan ajar gamifikasi dalam meningkatkan penalaran matematis siswa. Peningkatan penalaran matematis siswa pada kelas dengan perlakuan model pembelajaran Teams Games Tournament (TGT) menggunakan bahan ajar gamifikasi lebih baik dibandingkan dengan model pembelajaran konvensional.
\end{abstract}

Kata kunci : Teams Game Tournament; Bahan Ajar Gamifiasi; Pemahaman Matematis

\begin{abstract}
This research aims to improve students'mathematical understanding by applying the Team Game Tournament (TGT) learning model based on gamification teaching materials. Researchers used experimental research methods by adopting the Quasy Experiment Design. Researchers also used cluster random sampling so that class VIII A was obtained as an experimental class using the Teams Games Tournament (TGT) learning model, class VIII B was an experimental class that applied gamification teaching materials using the Teams Games Tournament (TGT) model, while class VIII $C$ was a class. control learning using traditional methods. The results show that there is an effect of the application of the Teams Games Tournament (TGT) learning model using gamification teaching materials in improving students' mathematical reasoning. The improvement of students' mathematical reasoning in the class with the Teams Games Tournament (TGT) learning model treatment using gamification teaching materials is better than the conventional learning model.
\end{abstract}

Keywords : Teams Game Tournament; Gamification Teaching Materials; Mathematical Understanding

\section{PENDAHULUAN}

Model pembelajaran merupakan salah satu aspek yang dapat menunjang keberhasilan penyampaian materi pembelajaran didalam kelas (Yakin, 2020); Sari et al (2021). Seperti yang diungkapkan oleh (Siang et al, 2020); Moma et al (2021); Santosa et al (2020); Tibahari dan Mulianan

(2018); Uskono et al (2020) mendefinisikan model pembelajaran sebagai suatu kerangka konseptual yang melukiskan prosedur secara sistematis dalam mengorganisasikan pengalaman belajar untuk mencapai tujuan belajar tertentu dan berfungsi sebagai pedoman bagi para perancang pembelajaran 


\section{$\pi$ (Phi)}

dan para pengajar dalam merencanakan dan melaksanakan aktivitas pembelajaran.

Dalam praktiknya didalam kelas, proses belajar dan pembelajaran masih dikatakan kurang efektif yang disebabkan oleh pemilihan model pembelajaran yang kurang tepat sehingga mengakibatkan pemahaman matematis siswa rendah. Rendahnya matematis siswa terjadi di sekolah MTs Negeri 1 Pringsewu.

Pada sekolah tersebut terdapat peserta didik yang masih banyak pasif didalam proses, kedapatan peserta didik yang tengah berbicara dengan temannya. Pada sekolah yang diteliti ternyata guru masih menggunakan metode konvensional seperti ceramah, tanya jawab, dan kerja kelompok atau berdiskusi.

Hal tersebut dibuktikan melalui hasil pra-survey yang dilakukan oleh peneliti yang bersumber pada intervew. Peneliti menginterview Ibu Nurwahidah S.Pd sebagai guru bidang studi Matematika kelas VIII MTs Negeri 1 Pringsewu. Ibu Nurwahidah S.Pd menjelaskan bahawa selama ini peserta didik memiliki kekurangan dalam hal mengerjakan masalahan yang berhubungan dengan aspek penalaran, dan masih banyak membutuhkan arahan dalam menyelesaikan permasalahan yang berkaitan dengan dengan penalaran matematis. Selain itu, peneliti juga mengamati hasil pemahaman matemais siswa yang disajikan pada tabel dibawah ini:

Tabel 1. Hasil Pra-Penelitian Penalaran Matematis

\begin{tabular}{lllll} 
Kelas & KKM & \multicolumn{2}{c}{ Nilai $(\boldsymbol{x})$} & Jumlah \\
\cline { 3 - 4 } & & $\mathbf{4 0 \leq \boldsymbol { x }}$ & $\mathbf{7 5 \leq \boldsymbol { x }}$ & \\
& & $<75$ & $<100$ & \\
\hline VII A & $\mathbf{7 5}$ & 15 & 15 & 30 \\
VII B & $\mathbf{7 5}$ & 18 & 12 & 30 \\
VII C & $\mathbf{7 5}$ & 22 & 10 & 32 \\
\hline
\end{tabular}

Berdasarkan tabel diatas dijelaskan bahwa hasil pra penelitian diklarifikasi menjadi 3 kategori nilai, yaitu nilai rendah, nilai KKM dan nilai tinggi. Dari tabel diatas dapat disimpulkan bahwa dari 3 kelas tersebut dengan jumlah 92 siswa nilai pra
Jurnal Pendidikan Matematika

Volume 5 Nomor 2 Tahun 2021

penelitian tertingi sebanyak 15 siswa dan yang mencukupi KKM sebanyak 37 siswa sedangkan nilai rendah sebanyak 55 siswa. Tes yang dilakukan di MTs N 1 Pringsewu ini meggunakan segitiga.

Lebih lanjut, guru juga mengugkapkan bahwa saat pembelajaran pendidik masih menggunakan bahan ajar yang berupa lembar kerja siswa atau yang biasa disebut dengan LKS yang digunakan oleh sekolat tersebut. Akibatnya proses pembelajaran dikelas terlihat begitu pasif karena peserta didik merasa jenuh pada saat proses pembelajaran. Didalam permasalahan seperti ini dibutuhkan sebuah model pembelajaran yang tepat serta bahan ajar yang menyenangkan atau yang bervariasi seperti bahan ajar berupa video, game atau yang lainnya.

Salah satu model pembelajaran yang dapat diaplikasikan didalam kelas yakni model pembeljaran Teams Game Tournament (TGT). Teams Game Tournament (TGT) merupakan salah satu tipe atau model pembelajaran kooperatif yang mudah diterapkan, melibatkan aktivitas seluruh siswa tanpa harus ada perbedaan status, melibatkan peran siswa sebagai tutor sebaya dan mengandung unsur permainan dan reinforcement (Mursyida (2021); Tussadiah dan Febriyana (2021); Asih dan Prihatnani (2021); Anggraeni dan Alpian (2020); Yunita el at (2020); Indah et al (2020); Saian et al (2020).

Selain model pembelajaran, peran bahan ajar juga berperan penting guna menunjang keberhasilan proses pembelajaran. Salah satu bahan ajar yang menyenankan adalah bahan ajar gamifikasi. Seperti yang dijelaskan oleh (Marisa et al (2020); Ristiana dan Dahlan (2021); Farida et al (2018); Aufa (2019); Rusli (2018) berpendapat bahwasanya gamifikasi merupakan penggunaan dari teknik desain permainan, permainan berpikir dan permainan mekanik untuk meningkatkan non-game konteks. Biasanya gamifikasi berlaku untuk non- 


\section{$\pi$ (Phi)}

game aplikasi dan proses, untuk mendorong orang untuk mengadopsi mereka, atau untuk mempengaruhi bagaimana mereka digunakan.

Peneliti melakukan penelitian yang berkaitan tentang penggunaan model pembelajaran TGT dengan pengadopsian gamifikasi yang berlandaskan penelitian terdahulu yang mengangkat tema penelitian yang serupa yakni (Suarimin (2020) mengungkapkan bahwa penggunaan gamifikasi untuk sekarang dan masa mendatang menjelaskan bahwa penggunaan sebuah produk dan mempunyai efek positif.

Sedangkan Sari et al (2020) berargumen bahwasanya gamification akan berpengaruh pada sisi kognitif dan psikomotor siswa ketika terlibat dalam gamification. Cara kita memberikan dorongan, penghargaan atas pencapaian sesuatu kepada peserta didik setelah berhasil menyelesaikan masalah merupakan inti dari gamification.

Dengan demikian peneliti ingin mengkaji lebih jauh tentang penggunaan model pembelajaran Teams Games Tournament (TGT) menggunakan bahan ajar gamifikasi untuk meningkatan penalaran matematis siswa.

\section{METODE PENELITIAN}

Pada penelitian ini, peneliti menggunakan metode penelitian eksperimen dengan mengadopsi Quasy Experiment Design. Saat melakukan penelitian, responden akan dibagi menjadi tiga kelompok. Kelompok pertama yaitu kelompok eksperimen 1, kelompok kedua yaitu kelas eksperimen 2, sedangkan kelompok ketiga yaitu kelas kontrol. Pembelajaran matematika yang akan dilakukan peneliti untuk kelas eksperimen 1 adalah menerapkan model pembelajaran Teams Games Tournament (TGT) menggunakan bahan ajar gamifikasi, pada kelas eksperimen 2 adalah menggunakan model Teams Games Tournament (TGT), sedangkan yang kelompok kontrol akan diberikan pembelajaran matematika menggunakan metode konvensional. Dalam pengambilan sampel, peneliti menggunakan cluster random sampling sehingga didapat kelas VIII A sebagai kelas eksperiment yang menggunakan model pembelajaran Teams Games Tournament (TGT), kelas VIII B kelas eksperiment yang menerapkan bahan ajar gamifikasi menggunakan model Teams Games Tournament (TGT), sedangkan kelas VIII C sebagai kelas kontrol yang pembelajarannya menggunkan metode tradisional.

\section{HASIL DAN PEMBAHASAN}

1) Analisis Data Awalan Atau Pretest Kemampuan Penalaran Matematis

Data hasil pretest didapat sebelum penelitian dimulai sesuai dengan perlakuan. Berdasarkan hasil yang diperoleh dari nilai pretest kemampuan penalaran matematis peserta didik diperoleh dari nilai tertinggi (maximum), nilai terendah (minimum), nilai rata-rata (mean), varians (variance), standar deviasi (Std. deviation), jumlah (sum), median, modus, dan jangkauan (range). Data hasil amatam awal dapat dilihat didalam tabel dibawah ini:

Tabel 2. Analisis Data Awalan (Pretest) Kemampuan Penalaran Matematis Peserta Didik

\begin{tabular}{cccc}
\hline & KELAS KONTROL & KELAS EKSPERIMEN 2 & KELAS EKSPERIMEN 1 \\
\hline ] $\quad$ Valid & 28 & 28 & 0 \\
Missing & 0 & 0 & 48.5118 \\
Mean & 47.2614 & 47.5239 & 47.9150 \\
Median & 47.9150 & 47.9150 & $41.67^{\mathrm{a}}$ \\
Mode & $41.67^{\mathrm{a}}$ & $41.67^{\mathrm{a}}$ & 8.27221 \\
Std. & 8.53782 & 8.95092 &
\end{tabular}

Deviation 
Variance

Range

Minimum

Maximum

Sum

\subsection{4}

25.50

33.33

58.83

1323.32

Dari hasil tabel diatas dapat dilihat bahwa data tersebut mempeproleh perbedaan rata-rata pretest kemampuan penalaran matematis peserta didik antara kelas eksperimen dan kelas kontrol. Berdasarkan data menunjukan bahwa kelas eksperimen memperoleh hasil lebih tinggi dibandingkan dengan kelas kontrol, tetapi selisih diantaranya tidak terlalu besar.

2) Uji Normalitas Data Pretest Kemampuan Penalaran Matematis

Tabel 3. Hasil Uji Normalitas Data Data Awalan (Pretest)

\begin{tabular}{crrrrrr}
\hline \multirow{2}{*}{ KELAS } & \multicolumn{3}{c}{ Kolmogorov-Smirnov ${ }^{\mathrm{a}}$} & \multicolumn{3}{c}{ Shapiro-Wilk } \\
\cline { 2 - 7 } & Statistic & Df & \multicolumn{1}{c}{ Sig. } & Statistic & Df & \multicolumn{1}{c}{ Sig. } \\
\hline ESKPERIMEN 1 & .127 & 28 & $.200^{*}$ & .952 & 28 & .227 \\
EKSPERIMEN 2 & .136 & 28 & .196 & .946 & 28 & .154 \\
KONTROL & .148 & 28 & .120 & .920 & 28 & .034 \\
\hline
\end{tabular}

Berdasarkan tabel diatas menunjukkan hasil uji normalitas data awalan (pretest) kkemampuan penalaran matematis pada Kolmogrof-Smirnov dengan melihat hasil sig pada masing-masing kelas eksperimen 1, kelas eksperimen 2 dan kelas kontrol yaitu 0,200, 0,196 dan 0,120 menunjukkan bahwa hasil tersebut lebih dari $a=0,05$. Oleh sebab itu, kelas ekspperimen 1, kelas eksperimen 2 dan kelas kontrol pada pretest dapat dinyatakan normal.
3) Uji Homogenitas Data Awalan (Pretest) Penalaran Matematis

Uji ini dilakukan untuk melihat apakah sampel mempunyaii variansi-variansi yang sama atau tidak pada penalaran matematis peserta didik. Uji homogenitas ini menggunakan aplikasi SPSS 25.0 yang menunjukkan Test Of Homogenity Variances untuk mengetahui apakah hasil tersebut homogen. Taraf yang digunakan untuk mengukur uji homogenitas yaitu $5 \%(a=0,05)$. Berikut hasil perhitungan uji homogenitas.

Tabel 4. Uji Homogenitas Data Awalan (Pretest) Penalaran Matematis Peserta Didik

\begin{tabular}{ccccc}
\hline & Levene Statistic & df1 & df2 & Sig. \\
\hline Based on Mean & .249 & 2 & 81 & .780 \\
Based on Median & .245 & 2 & 81 & .783 \\
Based on Median and with & .245 & 2 & 80.508 & .783 \\
$\begin{array}{c}\text { adjusted df } \\
\text { Based on trimmed mean }\end{array}$ & .249 & 2 & & \\
\hline
\end{tabular}

Berdasarkan hasil perhitungan menggunakan SPSS ppada tabel tersebut disimpulkan bahwa data dinyatakan diperoleh hasil 0,780 menunjukan bahwa homogen. Sig $>a$. Berdasarkan hasil tersebut dapat 


\section{4) Uji Hipotesis Data Awalan (Pretest)}

Setelah melakukan uji normalitas dan homogenitas dan diperoleh kesimpulan hasil bahwa data pretest ketiga kelas berdistribusi normal dan homogen. Maka dari itu, akan melakukan uji hipotesis menggunakan anava satu jalan dengan tujuan untuk melihat apakah data penelitian terhadap kelas eksperimen dan kelas kontrol mempunyai penalaran matematis yang sama. Berikut hasil uji anava satu jalan pada data pretest:

Tabel 5. Hasil Uji Anava Satu Jalan Data Awalan (Pretest) Dengan $a=0,05$

\begin{tabular}{cccccc}
\hline & Sum of Squares & Df & Mean Square & F & Sig. \\
\hline Between Groups & 24.343 & 2 & 12.171 & .165 & .848 \\
Within Groups & 5978.957 & 81 & 73.814 & & \\
Total & 6003.300 & 83 & & & \\
\hline
\end{tabular}

Berdasarkan hasil tabel diatas dapat dilihat bahwa Sig. 0,848 dan $a=0,05$ yang berarti $\mathrm{Sig}>a$ sehingga dapat disimpulkan bahwa tidak terdapat perbedaan yang tinggi dari nilai rata-rata antara kelas eksperimen dengan kelas kontrol.

5) Analisis Data Akhir (Posttest) Penalaran Matematis
Data hasil posttest didapat sebelum penelitian dimulai sesuuai perlakuan. Berdasarkan hasil yang diperoleh dari nilai posttest penalaran matematis peserta didik diperoleh data nilai tertinggi (maximum), nilai terendah (minimum), nilai rata-rata (mean), varians (variance), standar deviasi (Std. deviation), jumlah (sum), median, modus dan jangkauan (range). Data hasil amatan akhir dapat dilihat pada tabel dibawah ini:

Tabel 6. Analisis Data Akhiran (Posttest) Penalaran Matematis Peserta Didik

\begin{tabular}{cccc}
\hline & KELAS KONTROL & KELAS EKSPERIMEN 2 & KELAS EKSPERIMEN 1 \\
\hline Valid & 28 & 28 & 0 \\
Missing & 0 & 0 & 86.1636 \\
Mean & 80.6554 & 84.3750 & 87.5000 \\
Median & 83.3300 & 87.5000 & 91.67 \\
Mode & $79.17^{\mathrm{a}}$ & 91.67 & 8.78585 \\
Std. Deviation & 8.72665 & 10.67555 & 77.191 \\
Variance & 76.154 & 113.967 & 29.17 \\
Range & 25.00 & 33.33 & 70.83 \\
Minimum & 66.67 & 66.67 & 100.00 \\
Maximum & 91.67 & 100.00 & 2412.58 \\
Sum & 2258.35 & 2362.50 & \\
\hline
\end{tabular}

Berdasarkan tabel diatas dapat dilihat bahwa data tersebut memperoleh perbedaan rata-rata posttest penalaran matematis peserta didik antara kelas eksperimen 1, kelas eksperimen 2 dan kelas kontrol. Berdasarkan data menunjukkan bahwa kelas eksperimen memperoleh hasil yang lebih tinggi dibandingkan dengan kelas kontrol.
6) Uji Normalitas Data Posttest Penalaran Matematis

Uji normalitas berbantuan aplikasi SPSS 25.0 berdasarkan hasil tes kemampuan penalaran matematis peserta didik dengan menerapkan uji Kolmogrov-Smirnov dan melihat hasil Sig dari data tersebut. Sesuai dengan syarat normalitas bahwa dapat dikatakan data tersebut normal jika nilai 
yang didapatkan yaitu $p-$ value $>a$ (nilai dilihat pada tabel. $a=0,05$ ). Berikut hasil perhitungan dapat

Tabel 7. Hasil Uji Normalitas Dari Data Akhiran (Posttest)

\begin{tabular}{lrrrrrr}
\hline & \multicolumn{3}{c}{ Kolmogorov-Smirnov $^{\mathrm{a}}$} & \multicolumn{3}{c}{ Shapiro-Wilk } \\
\cline { 2 - 7 } \multicolumn{1}{c}{ KELAS } & Statistic & df & \multicolumn{1}{c}{ Sig. } & Statistic & df & Sig. \\
\hline KELAS EKSPERIMEN 1 & .127 & 28 & $.200^{*}$ & .951 & 28 & .214 \\
KELAS EKSPERIMEN 2 & .151 & 28 & .102 & .917 & 28 & .030 \\
KELAS KONTROL & .156 & 28 & .079 & .891 & 28 & .007 \\
\hline
\end{tabular}

Tabel 8. Uji Homogenitas Data Akhiran (Posttest) Penalaran Matematis Peserta Didik

\begin{tabular}{lrrrr}
\hline & Levene Statistic & df1 & df2 & \multicolumn{1}{c}{ Sig. } \\
\hline Based on Mean & 1.068 & 2 & 81 & .349 \\
Based on Median & .698 & 2 & 81 & .500 \\
Based on Median and with adjusted df & .698 & 2 & 76.046 & .501 \\
Based on trimmed mean & 1.062 & 2 & 81 & .351 \\
\hline
\end{tabular}

Berdasarkan hasil perhitungan menggunakan SPSS ppada tabel tersebut diperoleh hasil 0,349 menunjukan bahwa Sig $>a$. Berdasarkan hasil tersebut dapat disimpulkan bahwa data homogen.

7) Uji Data Akhiran (Posttest) Penalaran Matematis

Setelah melakukan uji normalitas dan homogenitas dan diperoleh kesimpulan hasil bahwa data posttest ketiga kelas berdistribusi normal dan homogen. Maka dari itu, akan melakukan uji hipotesis menggunakan anava satu jalan dengan tujuan untuk mengetahui apakah data penelitian terhadap kelas eksperimen dan kelas kontrol mempunyai penalaran matematis yang sama. Berikut hasil uji anava satu jalan pada data posttest:

Tabel 9. Hasil Uji Anava Satu Jalan Data Akhiran (Posttest) Dengan $a=0,05$

\begin{tabular}{lcrrrr}
\hline & \multicolumn{2}{c}{ Df } & F & Sig. \\
\hline Between Groups & 442.168 & 2 & 221.084 & 2.481 & .090 \\
Within Groups & 7217.447 & 81 & 89.104 & & \\
Total & 7659.615 & 83 & & \\
\hline
\end{tabular}

Berdasarkan hasil tabel diatas dapat dilihat bahwa Sig. 0,090 dan $a=0,05$ yang berarti Sig $>a$ sehingga dapat disimpulkan bahwa tidak terdapat perbedaan yang tinggi dari nilai rata-rata antara kelas eksperimen dengan kelas kontrol.
Setelah didapatkan data nilai pretest dan posttest, selanjutnya dapat mencari seberapa besar peningkatan penalaran matematis peserta didik dengan rumus gain ternormalitas (N-Gain). Utuk lebih jelasnya dapat dilihat dalam tabel dibawahini:

8) Analisis Amatan N-Gain Penalaran

Matematis

Tabel 10. Analisis Data N-Gain Penalaran Matematis Peserta Didik

\begin{tabular}{cccc}
\hline & KELAS KONTROL & KELAS EKSPERIMEN 2 & KELAS EKSPERIMEN 1 \\
\hline Valid & 28 & 28 & 28 \\
Missing & 0 & 0 & 0
\end{tabular}




\section{$\pi$ (Phi)}

Mean

Median

Mode

Std. Deviation

Variance

Range

Minimum

Maximum

Sum

Berdasarkan tabel tersebut dapat dilihat bahawa nilai $\mathrm{N}$-Gain dengan nilai maximum dikelas eksperimen 1 adalah 1,00, kelas eksperimen 2 adalah 1,00 dan kelas kontrol adalah 0,80 . Nilai minimum peserta didik pada kelas eksperimen 1 adalah 0,53, kelas eksperimen 2 adalah 0,50 dan kelas kontrol adalah 0,47 . Rataan nilai peserta didik pada kelas eksperimen 1 sebesar 0,7516 , kelas eksperimen 2 sebesar 0,7270 dan kelas kontrol sebesar 0,6492. Modus pada kelas eksperimen 1 adalah 0,64 , kelas eksperimen 2 adalah 0,50 dan kelas kontrol adalah 0,50. Nilai tengah (median) pada kelas eksperimen 1 adalah 0,7500 , kelas eksperimen 2 adalah 0,7500 dan kelas kontrol adalah 0,6670. Range nilai pada kelas eksperimen 1 adalah 0,47, kelas eksperimen 2 adalah 0,50 dan kelas kontrol adalah 0,33. Variansi nilai pada kelas eksperimen 1 adalah 0,019, kelas
Jurnal Pendidikan Matematika

Volume 5 Nomor 2 Tahun 2021

$\begin{array}{cc}.7270 & .7516 \\ .7500 & .7500 \\ .50^{\mathrm{a}} & .64^{\mathrm{a}} \\ .15652 & .13631 \\ .024 & .019 \\ .50 & .47 \\ .50 & .53 \\ 1.00 & 1.00 \\ 20.36 & 21.05\end{array}$

eksperimen 2 adalah 0,024 dan kelas kontrol 0,012 . Standar deviasi pada kelas eksperimen 1 adalah 0,13631, kelas eksperimen 2 adalah 0,15652 dan kelas kontrol adalah 0,10853. Jumlah nilai kelas eksperimen 1 adalah 21,05, kelas eksperimen 2 adalah 20,36 dan kelas kontrol 18,18 .

9) Uji Normalitas N-Gain Penalaran Matematis

Uji normalitas berbantuan aplikasi SPSS 25.0 berdasarkan hasil tes kemampuan penalaran matematis peserta didik dengan menerapkan uji Kolmogrov-Smirnov dan melihat hasil Sig dari data tersebut. Sesuai dengan syarat normalitas bahwa dapat dikatakan data tersebut normal jika nilai yang didapatkan yaitu $p-$ value $>a$ (nilai $a=0,05$ ). Hasil dari uji normalitas dapat dilihat pada tabel 11 .

Tabel 11. Hasil Uji Normalitas N-Gain

\begin{tabular}{|c|c|c|c|c|c|c|}
\hline \multirow[b]{2}{*}{ KELAS } & \multicolumn{3}{|c|}{ Kolmogorov-Smirnov a } & \multicolumn{3}{|c|}{ Shapiro-Wilk } \\
\hline & Statistic & Df & Sig. & Statistic & Df & Sig. \\
\hline KELAS EKSPERIMEN 1 & .133 & 28 & $200^{*}$ & .951 & 28 & .205 \\
\hline KELAS EKSPERIMEN 2 & .142 & 28 & .153 & .935 & 28 & .083 \\
\hline KELAS KONTROL & 144 & 28 & 146 & .908 & 28 & .018 \\
\hline
\end{tabular}

Berdasarkan tabel diatas menunjukkan hasil N-Gain kemampuan penalaran matematis pada Kolmogrof-Smirnov dengan melihat hasil sig pada masing-masing kelas eksperimen 1, kelas eksperimen 2 dan kelas kontrol yaitu $0,200,0,153$ dan 0,146 menunjukkan bahwa hasil tersebut lebih dari $a=0,05$. Oleh sebab itu, kelas ekspperimen 1, kelas eksperimen 2 dan kelas kontrol pada $\mathrm{N}$-Gain dapat dinyatakan normal.
10) Uji Homogenitas $N$-Gain Penalaran Matematis

Uji ini dilakukan untuk mengetahui apakah sampel memiliki variansi-variansi yang sama atau tidak pada penalaran matematis peserta didik. Uji homogenitas dilakukan dengan aplikasi SPSS 25.0 yang menunjukkan Test Of Homogenity Variances untuk mengetahui apakah hasil tersebut homogen. Taraf yang digunakan untuk mengukur uji homogenitas yaitu 5\% ( $a=$ 


\section{$\pi$ (Phi)}

$0,05)$.

11) Uji Hipotesis N-Gain Penalaran Matematis

Setelah melakukan uji normalitas dan homogenitas dan diperoleh kesimpulan hasil bahwa data $N$-Gain ketiga kelas berdistribusi normal dan homogen. Maka dari itu, akan melakukan uji hipotesis menggunakan anava satu jalan dengan tujuan untuk mengetahui apakah data penelitian terhadap kelas eksperimen dan kelas kontrol mempunyai penalaran matematis yang sama. Berikut hasil uji anava satu jalan pada data $N$-Gain:

Tabel 12. Hasil Uji Anava Satu N-Gain Penalaran Matematis Dengan

\begin{tabular}{ccccccc}
$a=0,05$ & \multicolumn{1}{c}{ Sum of } & Df & Mean Square & F & Sig. \\
\cline { 2 - 6 } & Squares & & 2 & .080 & 4.378 & .016 \\
\cline { 2 - 7 } & Between Groups & .160 & 81 & .018 & & \\
Within Groups & 1.481 & 83 & & & \\
Total & 1.641 & 83 & & & & \\
&
\end{tabular}

Berdasarkan hasil tabel tersebut didapatakan bahwa $\mathrm{Sig}<a$, karena Sig. Kurang dari 0,05 penulis dapat menyimpulkan peneliti harus melakukan uji lanjut komparasi ganda (Scheffe).
12) Uji Komparasi Ganda (Scheffe) N-Gain Penalaran Matematis

Setelah dilakukan uji anava satu jalan dengan hasil bahwa $H_{0}$ ditolak, maka langkah selanjutnya dilakukan uji komperasi ganda (Scheffe) dengan bantuan aplikasi SPSS 25.0 diperoleh data multiple comparasions sebagai berikut:

Tabel 13. Hasil Uji Komparasi Ganda N-Gain Penalaran Matematis Peserta Didik

\begin{tabular}{|c|c|c|c|c|c|c|}
\hline \multirow[t]{2}{*}{ (I) KELAS } & \multirow[t]{2}{*}{ (J) KELAS } & \multirow[b]{2}{*}{$\begin{array}{c}\text { Mean } \\
\text { Difference (I-J) }\end{array}$} & \multirow{2}{*}{ Std. Error } & \multirow[t]{2}{*}{ Sig. } & \multicolumn{2}{|c|}{$\begin{array}{l}\text { 95\% Confidence } \\
\text { Interval }\end{array}$} \\
\hline & & & & & $\begin{array}{l}\text { Lower } \\
\text { Bound }\end{array}$ & $\begin{array}{l}\text { Upper } \\
\text { Bound }\end{array}$ \\
\hline KELAS & KELAS & .02461 & .03614 & .794 & -.0655 & .1147 \\
\hline EKSPERIME & EKSPERIMEN 2 & & & & & \\
\hline N 1 & KELAS KONTROL & $.10243^{*}$ & .03614 & .022 & .0123 & .1926 \\
\hline KELAS & KELAS & -.02461 & .03614 & .794 & -.1147 & .0655 \\
\hline EKSPERIME & EKSPERIMEN 1 & & & & & \\
\hline N 2 & KELAS KONTROL & .07782 & .03614 & .105 & -.0123 & .1679 \\
\hline KELAS & KELAS & $-.10243^{*}$ & .03614 & .022 & -.1926 & -.0123 \\
\hline KONTROL & EKSPERIMEN 1 & & & & & \\
\hline & KELAS & -.07782 & .03614 & .105 & -.1679 & .0123 \\
\hline & EKSPERIMEN 2 & & & & & \\
\hline
\end{tabular}

Keterangan:

$\mu_{1}$ : Kelas penerapan model pembelajaran

Teams Games Tournament (TGT) menggunakan bahan ajar gamifikasi.

$\mu_{2}$ : Kelas menggunakan model pembelajaran Teams Games Tournament (TGT)

$\mu_{3}$ : Kelas menggunakan model pembelajaran konvensional

Berdasarkan tabel tersebut diperoleh hasil terhadap model pembelajaran masingmasing, dengan taraf signifikan 0,05, kesimpulan hasil sebagai berikut:

Pada $H_{0}: \mu_{1} \neq \mu_{2}$ didapat bahwa Sig 


\section{$\pi$ (Phi)}

memperoleh nilai 0,792 sehingga nilai sig $>0,05$, yang berarti tidak adanya perbedaan antara peserta didik menggunakan model pembelajaran temas games tornament (TGT) dan bahan ajar gamifikasi dengan peserta didik menggunakan model pembelajaran Teams Games Tournament (TGT) terhadap penalaran matematis. Hal ini karena siswa merasa kurang menarik saat proses pembelajaran yang tidak menggunakan bahan ajar dan hanya menggunakan model pembelajaran saja.

Selanjutnya pada $H_{0}: \mu_{1} \neq \mu_{3}$ didapat Sig memperoleh nilai 0,022 sehingga nilai sig $<0,05$, yang berarti yang berarti terdapat perbedaan signifikan antara peserta didik dengan menggunakan model pembelajaran Teams Games Tournament (TGT) dan bahan ajar gamfikasi dengan peserta didik menggunakan model konvensional terhadap penalaran matematis.

Pada $H_{0}: \mu_{2} \neq \mu_{3}$ didapat bahwa Sig memperoleh nilai 0,105 sehingga nilai sig $>0,05$, yang berarti tidak adanya perbedaan antara peserta didik menggunakan model pembelajaran Teams Games Tornament (TGT) dan bahan ajar gamifikasi dengan peserta didik menggunakan model konvesional terhadap penalaran matematis. Hal ini karena peserta didik kurang fokus terhadap terhadap arahan yang diberikan pada saat pemberian model pembelajaran.

Berdasarkan hasil penelitian dan uji hipotesis yang telah diperoleh diatas, untuk mengetahui model pembelajaran manakah yang memberikan peningkatan paling berbeda terhadap penalaran matematis peserta didik melalui uji komparasi ganda (Scheffe) menggunakan SPSS 25.0 dengan analisis sebagai berikut:

Hasil perhitugan anava satu jalan diperoleh nilai sig. 0,794<a, maka tidak adanya pengaruh yang signifikansi terhadap penalaran matematis antara penerapan bahan model pembelajaran Teams Games Tournament (TGT) menggunakan bahan ajar gamifikasi $\left(\mu_{1}\right)$ dengan menggunakan model
Jurnal Pendidikan Matematika

Volume 5 Nomor 2 Tahun 2021

pembelajaran Teams Games Tournament (TGT) $\left(\mu_{2}\right)$. Berdasarkan hasil rata-rata dapat disimpulkan bahwa penerapan model pembelajaran Teams Games Tournament (TGT) menggunakan bahan ajar gamifikasi sama baiknya dengan penggunaan model pembelajaran Teams Games Tournament (TGT) saja. Hal ini karena pada kelas yang menggunakan model pembelajaran Temas Games Tournaments (TGT) saja, peserta didik kurang fokus terhadap pembelajaran dengan faktor-faktor yang mungkin terjadi adalah kurangnya ketertarikan belajar siswa dalam mengikuti pembelajaran didalam kelas karena tidak adanya bahan ajar yang digunakan.

Hasil perhitungan anava satu jalan diperoleh nilai sig.0,022<a, berarti terdapat peningkatan yang signifikan terhadap penalaran matematis antara kelas yang menerapkan model pembelajaran Teams Games Tournament (TGT) menggunakan bahan ajar gamifikasi $\left(\mu_{1}\right)$ dengan kelas yang menggunakan model konvensional $\left(\mu_{3}\right)$. Berdasar hasil rata-rata, dapat ditarik kesimpulan penerapan model pembelajaran Teams Games Tournament (TGT) menggunakan bahan ajar gamifikasi lebih baik dibandingkan dengan model pembelajaran konvensional.Kelas dengan menerapkan model pembelajaran Teams Games Tournament (TGT) menggunakan bahan ajar gamifikasi lebih baik daripada kelas yang menggunakan model pembelajaran konvensional. Hal ini dikarenakan pada kelas yang menggunakan model konvensiuonal terlihat pasif, sehingga peserta didik cepat merasa jenuhb pada saat pembelajaran dan pembelajaran terasa membosankan. Oleh karena itu dalam penerapan model pembelajaran Teams Games Tournament (TGT) menggunakan bahan ajar gamfikasi lebih efisien digunakan dalam proses pembelajaran dan peserta didik terlihat lebih aktif dan tertararik dalam mengikuti pembelajaran.

Hasil perhitungan anava satu jalan 


\section{$\pi$ (Phi)}

diperoleh nilai sig. 0,105 $>a$, hal tersebut berarti tidak terdapat peningkatan yang signifikan terhadap penalaran matematis antara kelas yang menggunakan model pembelajaran Teams Games Tournament (TGT) $\left(\mu_{2}\right)$ dengan kelas yang menggunakan model konvensional $\left(\mu_{3}\right)$. Berdasarkan hasil rata-rata, dapat ditarik kesimpulan kelas yang menggunkan model pembelajaran Teams Games Tournament (TGT) tidak berpengaruh baik dengan kelas menggunakan model pembelajaran konvensi onalPada saat pembelajaran menggunakan model pembelajaran Temas Games Tournament (TGT) tanpa berbantuan bahan ajar peserta didik kurang fokus, karena bahan ajar gamifikasi tersebut adalah bahan ajar yang sangat menarik.

Pada penelitian yang telah dilaksanakan penggunaan bahan ajar samgan efisien dalam pembelajaran. Hal ini karena peserta didik lebih antusias dengan menggunakan bahan ajar sekaligus menggunakan model pembelajaran yang menarik. Tidak adanya pengaruh ketika merapkan kelas yang tidak diberikan bahan ajar ada beberapa faktor kemungkinan diantaranya, peserta didik lebih terlihat bosan tanpa adanya bahan ajar, daya tarik yang kurang maksimal dari peserta didik karena pasif nya keadaan didalam kelas dan letihnya peserta didik dalam pembelajaran didalam kelas menjadi salah satu faktor didalamnya.

\section{SIMPULAN DAN SARAN}

\section{Kesimpulan}

Berdasarkan penjabaran data yang telah dijelaskan tersebut peneliti menyimpulkan bahwasanya terdapat pengaruh penerapan model pembelajaran teams games tournament (TGT) menggunakan bahan ajar gamifikasi dalam meningkatkan penalaran matematis siswa. Peningkatan penalaran matematis siswa pada kelas dengan perlakuan model pembelajaran Teams Games Tournament (TGT) menggunakan bahan ajar gamifikasi lebih
Jurnal Pendidikan Matematika

Volume 5 Nomor 2 Tahun 2021

baik dibandingkan dengan model pembelajaran konvensional.

\section{Saran}

Saran yang penulis berikan dalam penelitian ini sebagai berikut:

Untuk pendidik, penerapan model Pembelajaran Teams Games Tournament (TGT) menggunakan bahan ajar gamifikasi bias dijadikan pilihan sebagai alternative yang bias dipakai supaya peserta didik lebih aktif dan antusias dalam proses pembelajaran sehingga penalaran matematis peserta didik menjadi lebih baik. Bagi peserta didik, sebaiknya jangan takut dan ragu untuk menuangkan ideatau menyampaikan pendapat saat proses pembelajaran berlangsung dan harus kerja sama yang baik dengan team ketika diharuskan berkelompok.

Selanjutnya untuk sekolah, sebaiknya, dapat menyampaikan atau menginformasikan kepada pendidik matematika mengenai model pembelajaran dan bahan ajar. Semoga apa yang diteiliti dapat dilanjutkan oleh penulis lain dengan penelitian yang lebih luas dan diharapkan dapat lebih kreatif, inovatif dalam menerapkan model pembelajaranTeams Games Tournament (TGT) menggunakan bahan ajar gamifikasi.

\section{DAFTAR PUSTAKA}

Asih, J. L., \& Prihatnani, E. (2021). Perbandingan Hasil Belajar Trigonometri dan Penerapan STAD dan TGT Ditinjau Atas Tingkat Kecemasan. Jurnal Cendekia: Jurnal Pendidikan

Matematika, 5(1), 259-273.

Anggraeni, S. W., \& Alpian, Y. (2020). Membaca Permulaan Dengan Teams Games Tournament (TGT). Penerbit Qiara Media.

Aufa Bharata, A. (2019). Rancang Bangun Aplikasi Pengembangan Atlet Taekwondo Berbasis Android 
$\pi$ (Phi)

dengan Metode Gamifikasi (Studi Kasus: Unit Kegiatan Mahasiswa Taekwondo Universitas Multimedia Nusantara) (Doctoral dissertation, Universitas Multimedia Nusantara)

Farida, F., Khoirunnisa, Y., \& Putra, R. W. Y. (2018). Pengembangan Bahan Ajar Gamifikasi Pada Materi Bangun Ruang Sisi Lengkung. JPPM (Jurnal Penelitian dan Pembelajaran Matematika), 11(2).

Indah Yuniarti, T., Badariah, B., \& Wendra, B. (2020). Pengaruh Model Pembelajaran Teams Games Tournament (TGT) Menggunakan Kartu Domino Terhadap Hasil Belajar Ilmu Pengetahuan Alam (IPA) (Doctoral dissertation, UIN Sulthan Thaha Saifuddin Jambi).

Marisa, F., Akhriza, T. M., Maukar, A. L., Wardhani, A. R., Iriananda, S. W., \&

Andarwati, M. (2020). Gamifikasi ( Gamification) Konsep dan Penerapan. JOINTECS (Journal of Information Technology and Computer Science), 5(3), 219-228.

Moma, L., Tamalene, H., \& Ramadhani, W. P. (2021). Pengembangan Alat Model Pembelajaran Inkuiri pada Mata Kuliah Kalkulus Lanjut. Jurnal Padegogik, 4(1), 2231.

Mursyida, Y. I. (2021). Meningkatkan Hasil Belajar Matematika Melalui Model Kooperatif TGT (Teams Games Tournament) pada Siswa Kelas VIIIB SMP Negeri 5 Jember. Education Journal: Journal Educational Research and Development, 5(1), 139-150.

Ristiana, M. G., \& Dahlan, J. A. (2021). Pandangan Mahasiswa Calon Guru Dalam Penggunaan Model Gamifikasi Dalam Pembelajaran Matematika. JPMI (Jurnal Pembelajaran Matematika
Jurnal Pendidikan Matematika

Volume 5 Nomor 2 Tahun 2021

Inovatif), 4(1), 127-136.

Rusli, A. (2018). Ekstraksi Kebutuhan Aplikasi Berdasarkan Feedback Pengguna Menggunakan Naïve Bayes dan Gamifikasi. Ultimatics: Jurnal Teknik Informatika, 10(1), 34-40.

Saia, G., Mandang, F., \& Paath, R. C. (2020). Pembelajaran Memahami Struktur Teks Prosedur Melalui Model Teams Games Tournament (TGT) Pada Siswa Kelas VIII SMP Negeri $1 \quad$ Essang. Jurnal Bahtra, 1(1).

Siang, J. L., Sukardjo, M., Salenussa, B. J., Sudrajat, Y., \& Khasanah, U. (2020). Pengaruh Model Pembelajaran dan Kemampuan Berpikir Kreatif Terhadap Hasil Belajar IPA Siswa SMP. JTPJurnal Teknologi Pendidikan, 22(1), 40-52.

Sari, E. I., Wiarsih, C., \& Bramasta, D. (2021). Strategi Guru Dalam Meningkatkan Keterampilan Membaca Pemahaman Pada Peserta Didik di Kelas IV Sekolah Dasar. Jurnal Educatio FKIP UNMA, 7(1), 74-82.

Sari, S. A., Istihana, I., Putra, R. W. Y., Sodiq, A., \& Tuala, R. P. (2020, June). Model pembelajaran TAI pada bahan ajar gamifikasi: Dampak terhadap pemahaman konsep siswa pada materi sistem persamaan linear. In Prosiding Seminar Nasional Matematika dan Pendidikan Matematika (Vol. 3, No. 1, pp. 1-10).

Santosa, D. S. S., Sampaleng, D., \& Amtiran, A. (2020). Meningkatkan Prestasi Belajar Siswa Melalui Model Pembelajaran. SIKIP: Jurnal Pendidikan Agama Kristen,1(1), 11-24.

Suarmini, M. (2020). Metode Gamifikasi Berbasis Tri Hita Karana Sebagai Alternatif Pembelajaran 


\section{$\pi$ (Phi)}

Abad 21. Maha Widya Bhuwana: Jurnal Pendidikan, Agama dan Budaya, 2(2), 42-47.

Tibahary, A. R., \& Muliana, M. (2018). Model-model Pembelajaran Inovatif. Scolae: Journal of Pedagogy, 1(1), 54-64.

Tussadiah, H., \& Febriyana, M. (2021). The Analysis of the Effectiveness of Team Type Cooperative Learning Model Tournament (TGT) Based on the Snake and Ladder Game Media in Indonesian Literature Online Material during the Covid-19 Pandemic. Budapest

International Research and Critics Institute (BIRCIJournal): Humanities and Social Sciences, 4(1), 780-786.

Uskono, I. V., Djong, K. D., \& Leton, S. I. (2020). Penerapan Model Pembelajaran Matematika
Jurnal Pendidikan Matematika Volume 5 Nomor 2 Tahun 2021

Realistik Pada Pokok Bahasan Bilangan Bulat. Range: Jurnal Pendidikan Matematika, 1(2), 138-144.

Yakin, A. (2020, November). Metode Diskusi Dalam Pembelajaran Menurut Perspektif Islam. In Annual Conference on Islamic Education and Thought (ACIET) (Vol. 1, No. 1, pp. 157163).

Yunita, A., Juwita, R., \& Kartika, S. E. (2020). Pengaruh penerapan model pembelajaran kooperatif tipe teams games tournament terhadap hasil belajar matematika siswa. Mosharafa: Jurnal Pendidikan Matematika, 9(1), 23-34. 